\title{
PREDICTION OF SCOUR DEPTH AROUND BRIDGE PILES USING ARTIFICIAL NEURAL NETWORKS
}

\author{
K. A. Amen ${ }^{*}$ and Yasser M. R. \\ * Lecturer of irrigation, water construction, and water resources, \\ Civil Engineering Dept, Assiut university, Assiut, Egypt \\ **Lecturer of irrigation, water construction, and water resources, \\ Civil Engineering Dept, Assiut university, Assiut, Egypt
}

(Received November 4, 2008 Accepted February 23, 2009)

\begin{abstract}
The safe and economical design of bridge piles requires prediction of the maximum expected depths of scour of the stream bed around them. Scour at bridge piles may be defined as a local lowering in the bed elevation around the piles. A study of the local scour at bridge piles groups was experimentally and mathematically investigated. The case of six piles having the same diameter aligned with the flow direction in two rows altering the separation distance between the centerline of the three piles was established. The aim of this study is the investigation of the preferable separation distance between three piles to reduce scour around them to its minimum value.

Artificial Neural Network (ANN) prediction models are more efficient in predictions models once they are trained from examples or patterns. These types of ANN models need large amount of data which should be at hand before thinking to develop such models. In this paper, the capability of ANN model to predict the maximum scour depth around bridge piles is investigated.
\end{abstract}

\section{INTRODUCTION AND REVIEW}

Each year millions of dollars are spent in the world to repair, reconstruct, or replace bridges whose piers have been undercut by the scouring action of stream flow. For friction piles foundation the resistance at the sides of the piles equals to the load coming on them. The total frictional resistance of piles is obtained by multiplying frictional resistance of soil with the area of pile in contact with it. Therefore, the elevation of the stream bed in the vicinity of the piles, pier and abutments must be known. The elevation in question, however, is not the elevation at the time a survey happened to be made, but the lowest elevation which will occur during the anticipated life of the bridge. The local scour was discussed by numerous of investigators, see e.g. Baghdadi [1], Blaisdell, F.W., Anderson, C.L., and Hebaus, G.G., [2], Carstens, [3], Farhoudi [4], Groot [5], Hong [6], and many others. scour called:-

Ali and Hadya [7] mentioned that, in practice there are three cases of local

(1) Stable scour: the sediment discharge entering the scour hole is equal to the sediment discharge from the scour hole, 
(2) Clear water scour: the flow of sediment into the scour hole is zero. The erosion is continuous and the depth of scour increases with time until a limiting value is reached, and

(3) Scour with varying sediment inflow : the inflow of sediment from upstream may be smaller or greater than the rate of sediment discharge from the scour hole so that the depth of scour increase or decrease with time respectively.

Hoffmans [8] distinguished four phases in the evolution of a scour hole based on Breusers, an initial phase, a development phase, a stabilization phase, and an equilibrium phase. Also, He illustrated that the bed load at the upstream scour slope during the equilibrium phase is negligibly small and the equilibrium situation of upstream scour slope is achieved by mean bed load from the instantaneous bed shear stresses sloping downward with the mean bed load resulting from the instantaneous bed shear stresses sloping upward. The sediment particles are only moving and rolling along the bed surface (no suspension).

\section{DIMENSIONAL ANALYSIS}

The variables used for the dimensional analysis are chosen to represent all the parameters involved in the problem. See figure (1) and appendix. The general functional relationship for these variables is given in the following from:

$$
d_{s}=\Phi(y, v, D, \rho, g, s)
$$

Applying the Buckingham's theorem in which $Y, V$, and $\rho$ are selected as the repeating variables, the following non - dimensional groups will result :

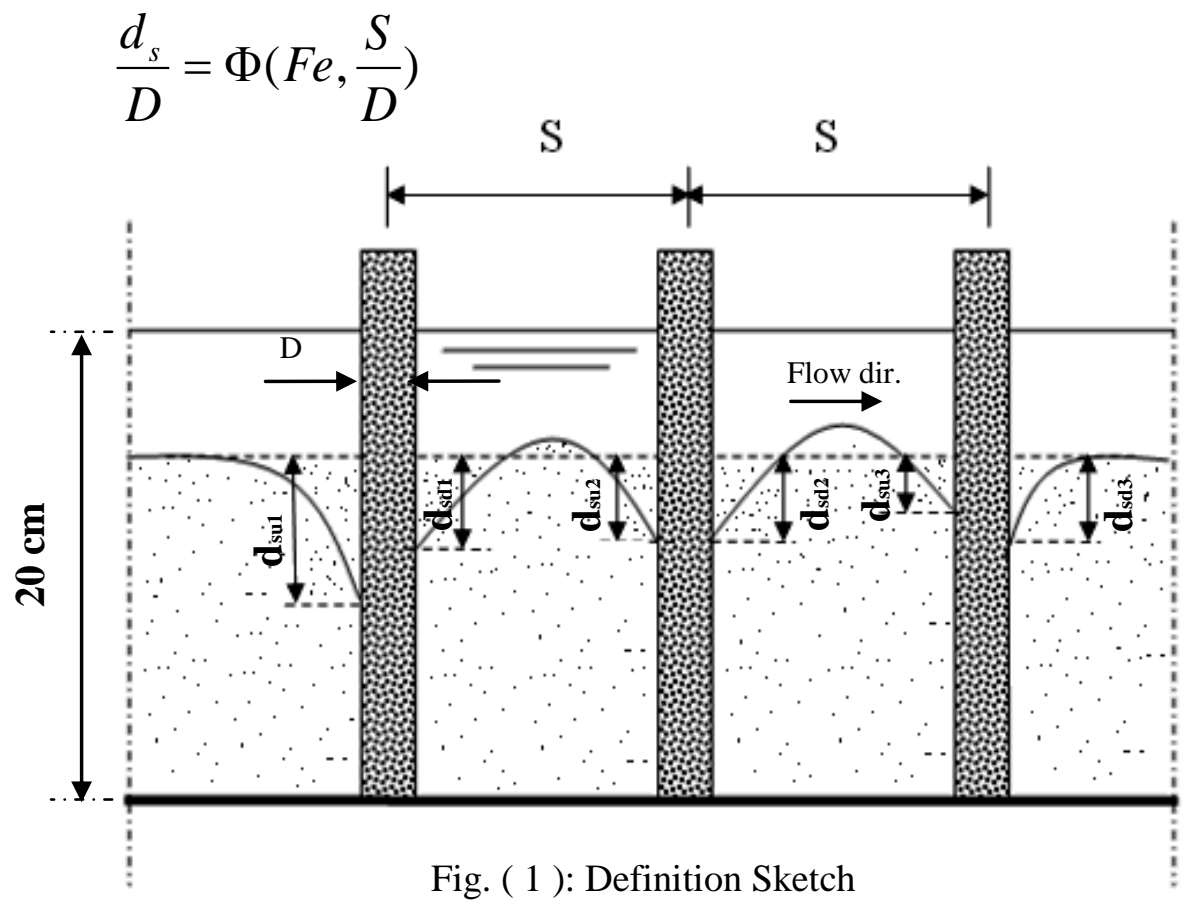




\section{COLLECTION OF EXPERIMENTAL DATA}

The experimental data that is used to train, validate and test the ANN model were collected using a rectangular channel $10.50 \mathrm{~m}$ long, $1.50 \mathrm{~m}$ wide, $1.35 \mathrm{~m}$ deep and longitudinal slope 0.001 . Figure (2) shows a schematic diagram of the experimental facility. Water is supplied from the laboratory closed system. Figure (3) shows a diagrammatic sketch of the circulating water circuit, and the direction of the flow. Experiments were carried out under the condition of clear water and no uniform bed sediments. Four diameters of wooden piles (see fig. (4) ) were prepared for only two piles aligned perpendicular to the stream flow and then another group of experiments were conducted for six piles of the same diameters in two rows altering the separation distance between the centerline of the three piles. This experimental work was carried out at four discharge of water. The discharge was measured by a calibrated right angle $\mathrm{V}$-notch installed at end of the channel basin.
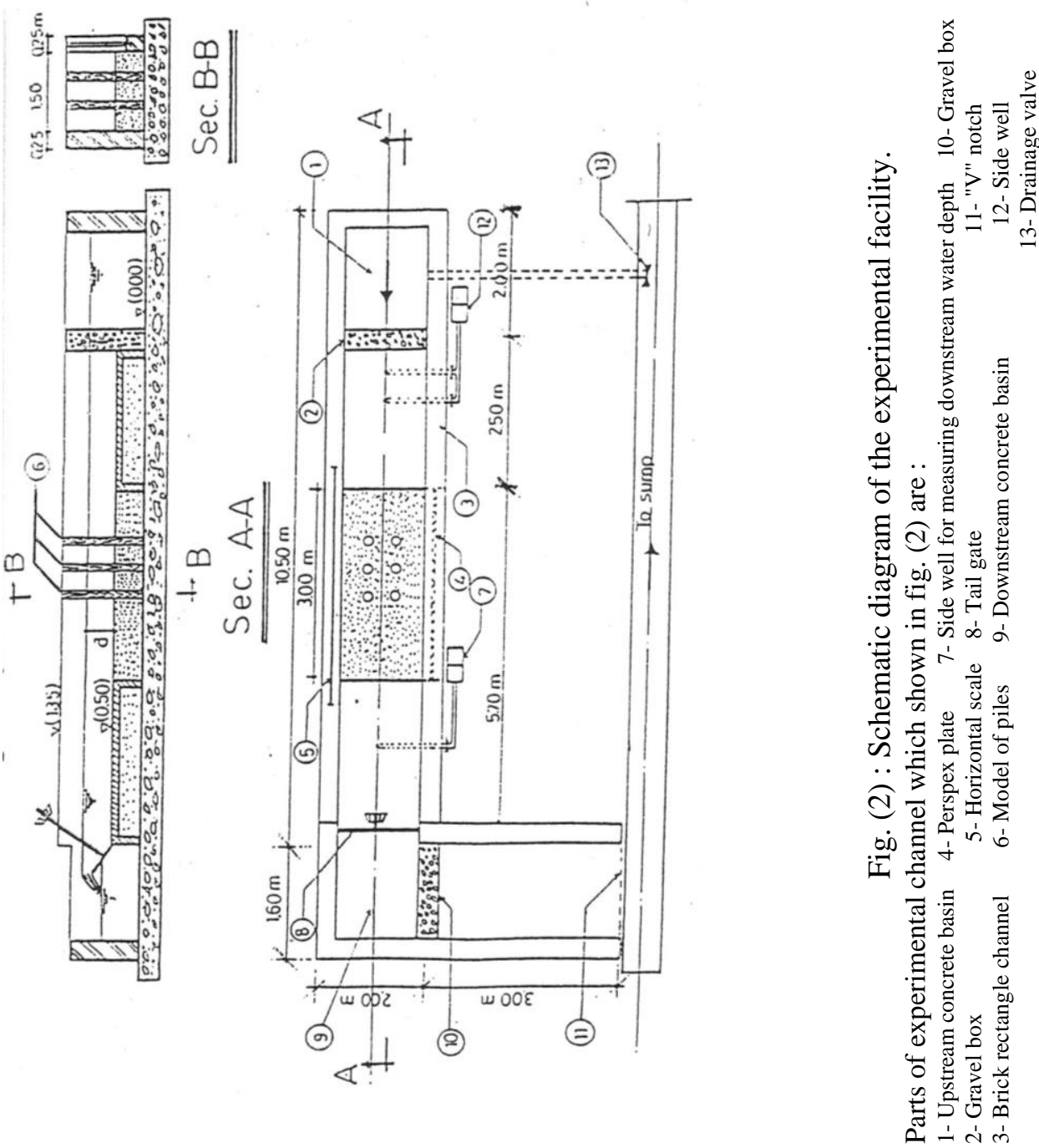


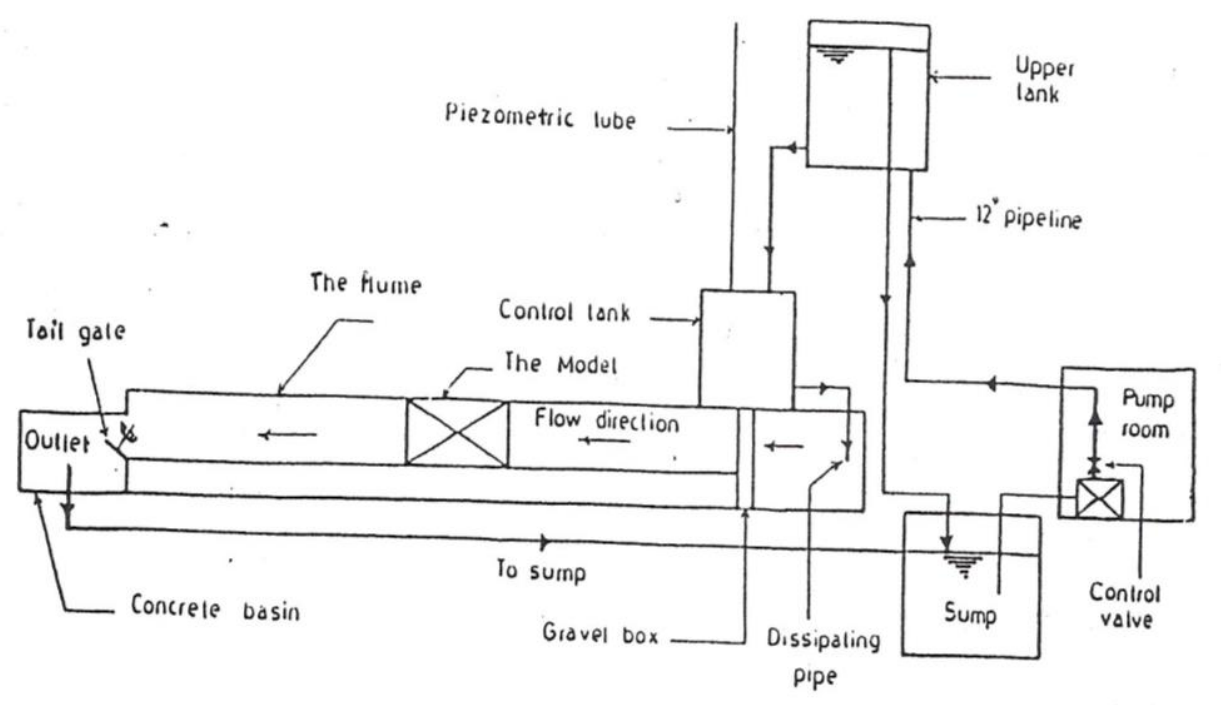

Fig. (3): Schematic diagram of circulating in the laboratory.

\section{RUN PROCEDURE}

To measure the scour hole around first, second, and third bridge piles having the same diameter and placed at distance " S" centerline to centerline, experiments were carried out keeping the channel depth and bed sediments at to constant values in all runs while the discharge is variable. The channel depth was $20 \mathrm{~cm}$, d50 of the sediment bed was $0.62 \mathrm{~mm}$, and the mean water velocity was $16.47,18.82,21.57$ and $23.14 \mathrm{~cm} / \mathrm{sec}$.

The following procedure was considered in all experimental work :

1- For each of the four pile sizes, the piles were fixed at the bottom of the channel and the bed sediment was leveled by the vernier point gauge.

2- Channel bed sediment was saturated to release air voids and the bed was relevelled to appoint zero scour depth on the micrometer.

3- Water flow was allowed to enter the channel gradually until an initial water depth was reached, then the pump control valve was released gradually to obtain the required rate of water flow. The gate at the downstream end of the flume was adjusted to give the required constant flow water depth $20 \mathrm{~cm}$.

4- Water flow was recirculated till an equilibrium scour hole was practically obtained after about four hours.

5- Water flow was gradually stopped and the channel was drained slowly.

6- The levels of the scour hole were measured and the scour hole was drawn showing the length of the of the scoured hole.

7- The position and the value of the maximum scour depth determined.

8- The above procedure was repeated considering six piles in two rows of the same diameter in aligned with the flow direction. 


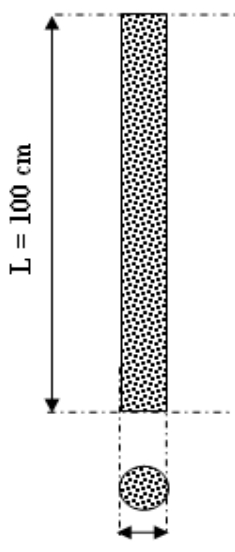

$\mathrm{D}$

\begin{tabular}{|c|c|c|}
\hline D(cm) & L (cm) & Number \\
\hline 5 & 100 & 6 \\
\hline 6 & 100 & 6 \\
\hline 7 & 100 & 6 \\
\hline 8 & 100 & 6 \\
\hline
\end{tabular}

Fig. (4) : Model of the used piles

\section{BASICS OF ANN}

Artificial Neural Network (ANN) were originated to simulate the structure and function of brain but are much more simpler than the more complicated brain. All types of ANN have the ability to learn from data. The ANN may learn in supervised or unsupervised way. In the supervised learning, which is adopted in this study, the ANN learns and yields outputs that are compared to the desired ones to determine the errors. Then, the learning algorithm modifies the weights of the connections between the processing elements (neurons), so that the errors are reduced at the end of the next iteration. So many iterations are made till the network performed well. One of the most common learning algorithms is the back propagation. More information on this learning algorithm and others are found in specialized textbooks in neural networks as Negm [9], 2004.

Figure (5) shows a typical feed forward back propagation network. It has three layers. The input layer where the input data of the input variables are presented to the network. The number of neurons (nodes / cells / neurons or elements ) is determined by the number of input variables. For the scour around piles, two input variables are involved, namely, the Froude number Fe and the ratio between the distance from centerline to centerline of piles and the diameter of pile S/D. the output layer consists of a number of neurons equals the number of dependent variables ( output variables ) to be predicted. In the present application, six output variables are involved, namely : $d_{s u 1}=$ the upstream scour depth for the first pile.

$d_{s d 1}=$ the downstream scour depth for the first pile.

$d_{s u 2}=$ the upstream scour depth for the second pile.

$d_{s d 2}=$ the downstream scour depth for the second pile.

$d_{s u 3}=$ the upstream scour depth for the third pile.

$d_{s d 3}=$ the downstream scour depth for the third pile. 
One or more layers in between the input and the output layers may be involved and are called hidden layers because they do not interface with the user and the entire processing is not accessible. The neurons are connected by links or connections that hold the key to learn through iterative adjustments of the weights on these links. The output data to the input layer are combined by the weights on the links between the input layer and the next layer through a combining function as that defined by Eq.(3). Then a nonlinear transfer function is applied to the resulting signal (I) to yield the output of the hidden layer (h). The hyperbolic tangent is used in this study as the nonlinear transfer or the activation function. The output of Eq.(4) is then combined with the weights of the connections between the hidden layer and the output layer by the combination function defined by Eq. (5) to yield the output of the network $(\mathrm{O})$.

$$
\begin{aligned}
& I_{j}=\sum_{j=1}^{m} x_{i} w_{i j}+b_{j} \\
& h_{j}=\frac{\exp \left(I_{j}\right)-\exp \left(-I_{j}\right)}{\exp \left(I_{j}\right)+\exp \left(-I_{j}\right)} \\
& O_{k}=\sum_{j=1}^{n} h_{j} C_{j k}+b_{k}
\end{aligned}
$$

Where $x_{i}$ is the input of the neuron $\mathrm{i}$ in the input layer with $\mathrm{m}$ being the number of neurons in the input layer and bj is the bias of the unit. The Wij is the weight vector of the connections between the neurons of the input layer and the neurons of the hidden layer. $\mathrm{Cjk}$ is weight of the connection between neuron $\mathrm{j}$ of the hidden layer and neuron of the output layer, $n$ is the number of neurons in the hidden layer and bk is the bias to the neuron $\mathrm{k}$.

$$
\text { Input layer hidden layer output layer }
$$

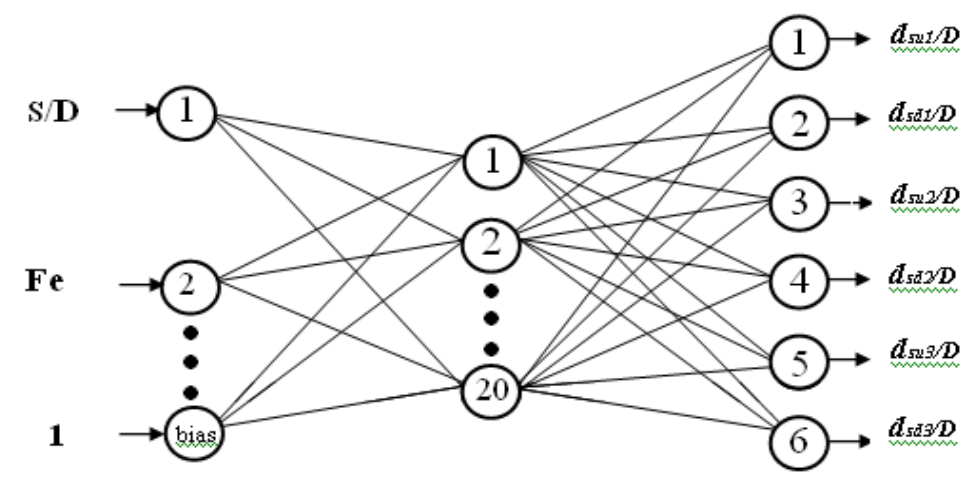

Figure (5): The multilayer feed forward back- propagation ANN. 


\section{RESULTS OF THE DEVELOPED ANN MODEL}

Many computer experiments were conducted to determine the best initial range of the weights of the network connections, the best activation function, the best number of neurons in the hidden layer and the best number of iterations, see figures (6), (7), (8), and (9). Then the network stability was checked. Analysis of the results of the conducted experiments indicated that:

The best range to initialize the weight matrix was $+/-0.2$.

The best activation function was tanch.

The best number of neurons in the hidden layer was 20 neurons.

The best number of iterations was 400 iterations (maximum updates) which gives higher coefficient of determination $\left(R^{2}\right)$.

Multiple linear regression analysis are used to develop statistical prediction model to predict the maximum depth of scour around bridge pile in terms of Froud Number and the ratio S/D, eq. from (6) to (11) have correlation coefficient $R^{2}=0.821$ and standard deviation of estimate of 0.465 .

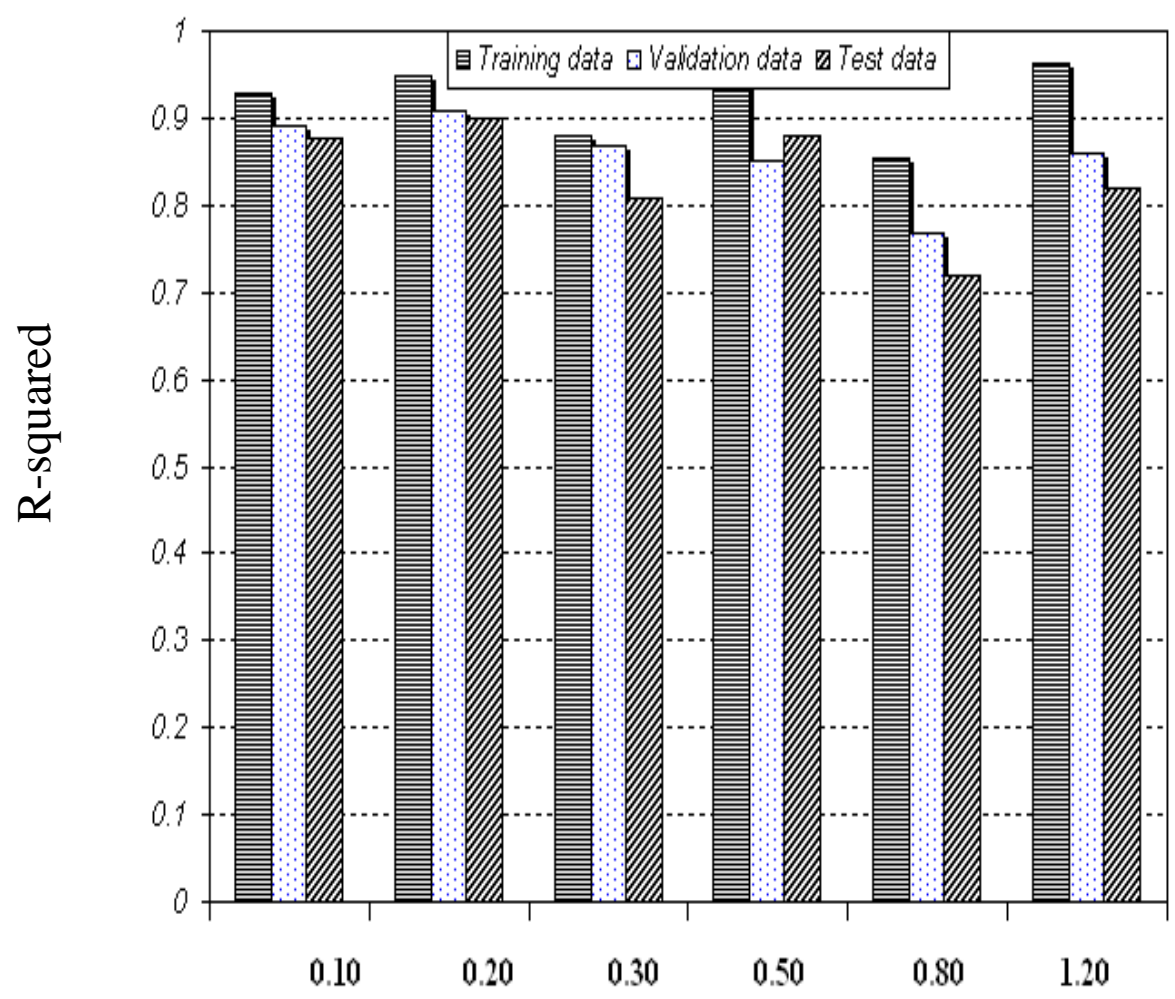

\section{(+/-) Weight}

Fig. (6): Values of R-squared, versus weights (Topology 2-20-6) 


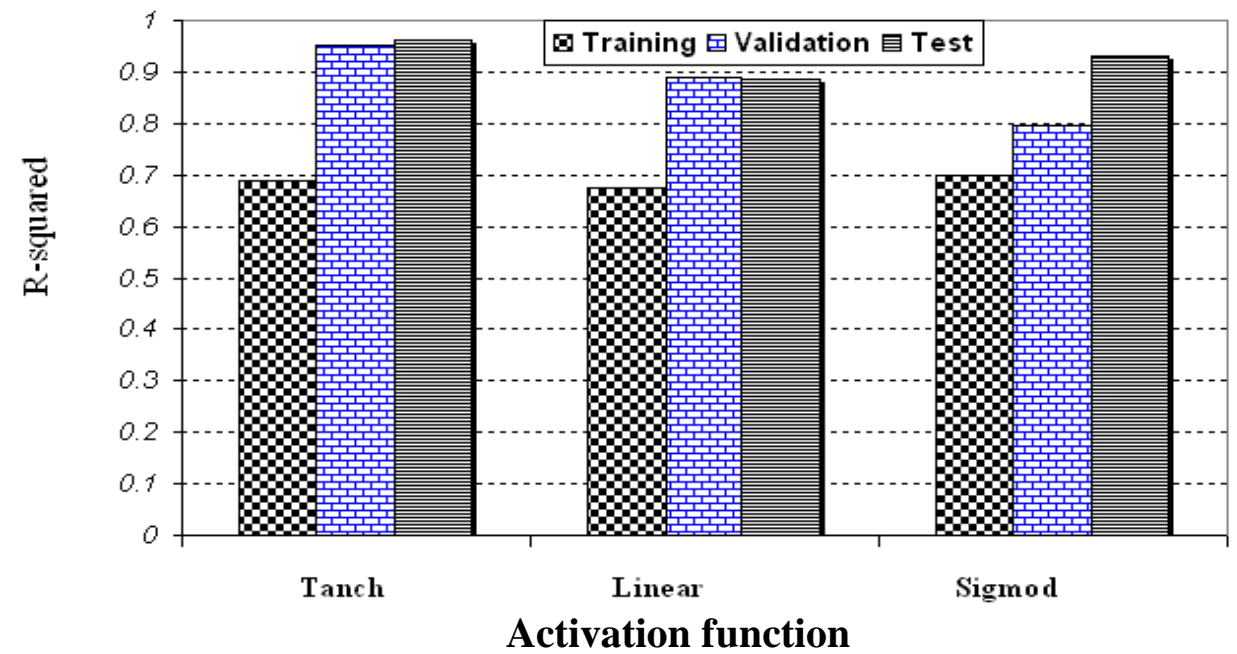

Fig. (7): Values of R-squared, versus activation function (Weight $=+/-0.2$ )

$$
\begin{aligned}
\frac{d_{s u 1}}{D} & =6.32 F_{e}+0.016\left(\frac{S}{D}\right) \\
\frac{d_{s d 1}}{D} & =4.97 F_{e}+0.026\left(\frac{S}{D}\right) \\
\frac{d_{s u 2}}{D} & =1.583 F_{e}+0.05\left(\frac{S}{D}\right) \\
\frac{d_{s d 2}}{D} & =0.978 F_{e}+0.018\left(\frac{S}{D}\right) \\
\frac{d_{s u 3}}{D} & =3.331 F_{e}+0.040 \oint\left(\frac{S}{D}\right) \\
\frac{d_{s d 3}}{D} & \left.=0.0099 F_{e}-0.022 \oint \frac{S}{D}\right)
\end{aligned}
$$

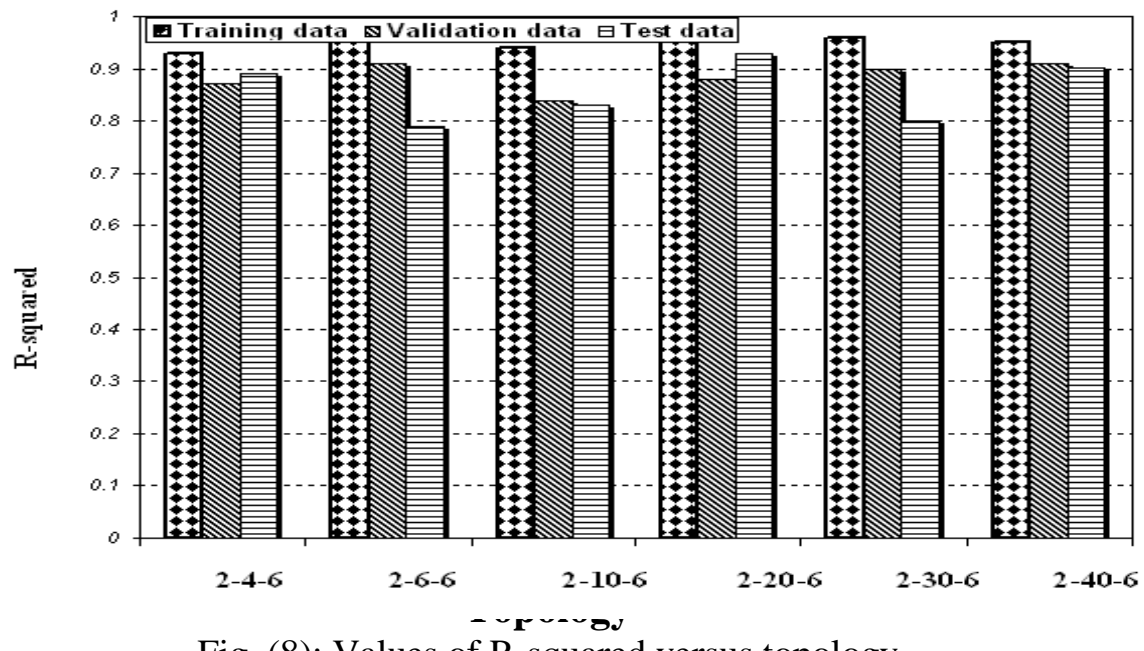

Fig. (8): Values of R-squared versus topology 


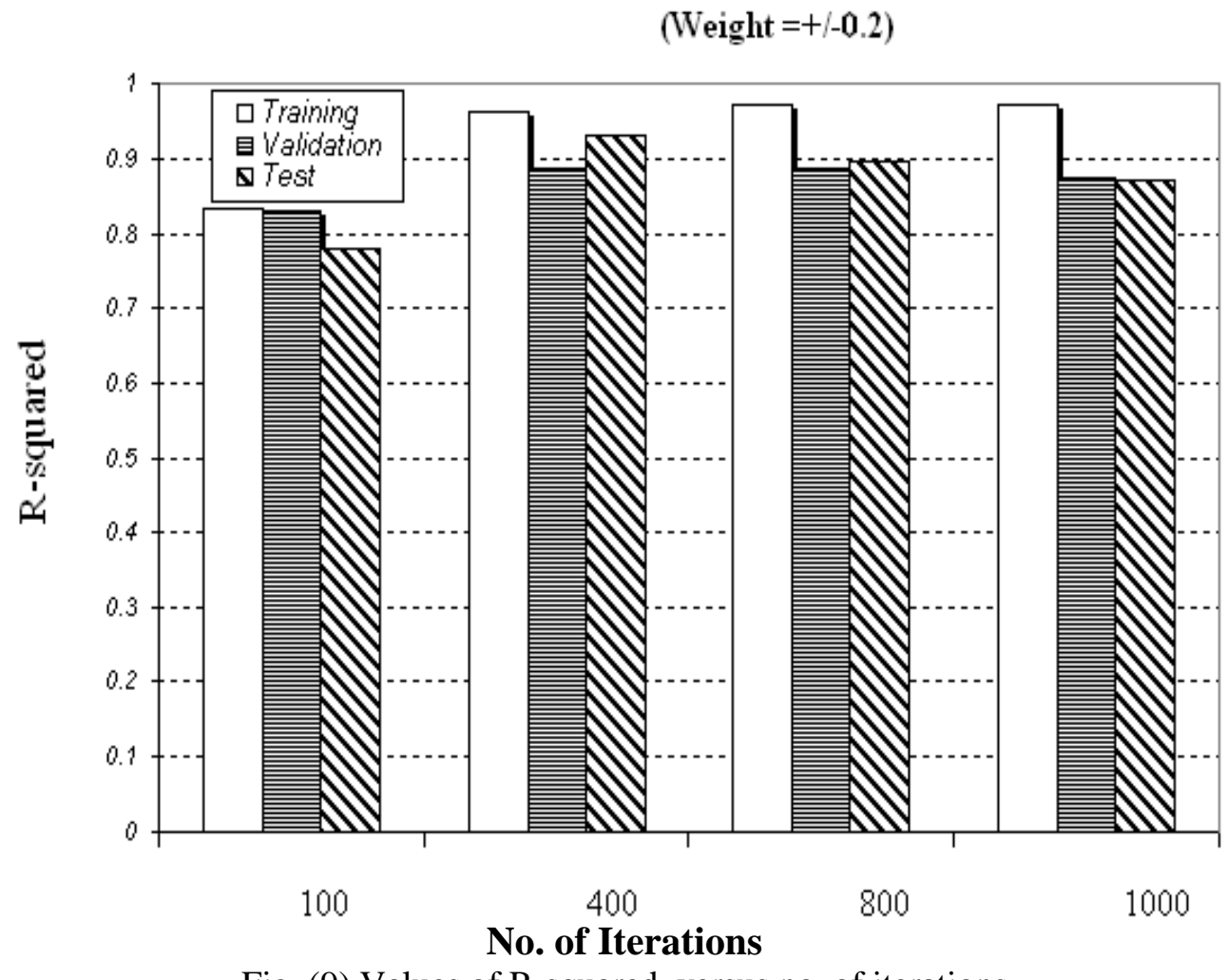

Fig. (9) Values of R-squared, versus no. of iterations

(Weight $=+/-0.2$ )

Figure (10) shows the comparison between the predication of the best network (2-20-6) and the experiment data. The figure indicated that fair agreement was obtained. Also, it is noticeable that the upstream scour depths increase with the increase of Froud Number. These scour depths reach a maximum values at Froud number equal to 0.167 , after these values differ slightly.

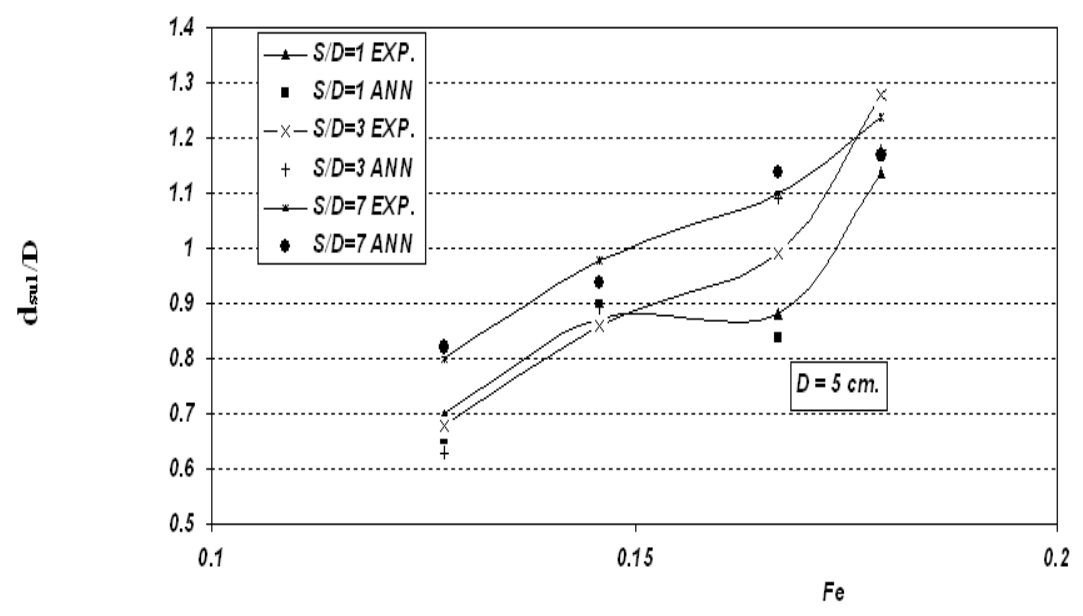

Fig. (10): Comparison between the predication of the best network (2-20-6) and the experiment data. 
Figure (11) shows the relationship between maximum scour depth upstream single pile and piles diameters. According to this curve, the maximum scour depth upstream the pile increases with increase in pile diameter, reaching an absolute maximum value at $\mathrm{D}=7 \mathrm{~cm}$. then decreases slightlv with the diameter more than 7

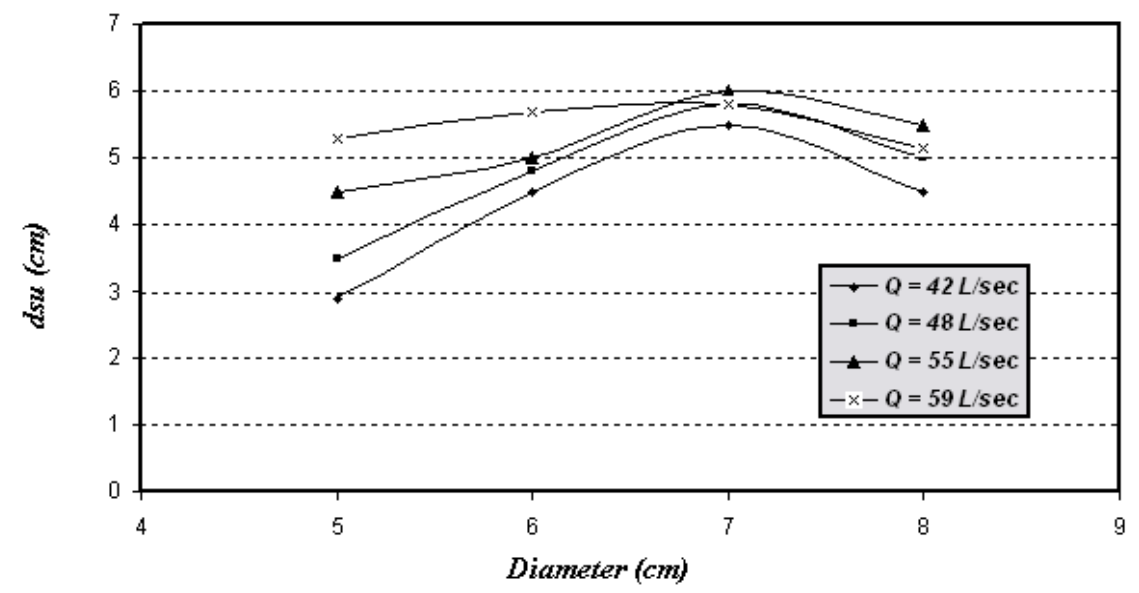

Fig. (11): Moximum Scour depth upstream pile versus piles diameter.

\section{CONCLUSIONS}

1- The maximum scour depth occurs upstream the pile

2- The side slopes of the scour hole are approximately equal to the natural angle of repose of the bed material.

3- The maximum scour depth upstream the pile increases with the increase of pile diameter.

4- The upstream scour depths increase with increasing pile separation distance reaching a maximum values at $S / D=9$ and a minimum values at $S / D=2$ to 5 .

5- The upstream scour depths decrease with increasing the ratio S/D more than 9.

6- The upstream scour depths increase with the increase of Froud Number reaching an absolute maximum value at $\mathrm{Fe}=0.167$, after these values differ slightly.

7- There are agreement between experimental data and ANN model.

\section{SUGGESTION FOR FUTURE WORK}

1- $\quad$ Studying the effect of pile shape (square - rectangle) on local scour.

2- $\quad$ Studying the influence of enlarging the pile diameter near the region of foundation.

3- $\quad$ Studying the effect of attack angle on local scour.

4- $\quad$ Studying the effect of type and size of material bed sediment on local scour. 


\section{NOMENCLATURE}

$d_{s u i}=$ the upstream scour depth for the first pile.

$d_{s d 1}=$ the downstream scour depth for the first pile.

$d_{s u 2}=$ the upstream scour depth for the second pile.

$d_{s d 2}=$ the downstream scour depth for the second pile.

$d_{s u 3}=$ the upstream scour depth for the third pile.

$d_{s d 3}=$ the downstream scour depth for the third pile.

$d_{s}=$ the maximum scour depth.

$D=$ the diameter of pile.

$\mathrm{Fe}=$ Froud Number.

$G=$ the gravity acceleration.

$V=$ the mean velocity.

$S=$ the distance from centerline to centerline of piles.

$Y=$ the water depth.

$\rho=$ the flow density

\section{REFERENCES}

1. Baghdadi, K.H., "Prediction of Bed Forms in Alluvial Channels "Alexandria Engineering Journal, Vol. 34, No. 5, December 1995.

2. Blaisdell, F.W., Anderson, C.L., and Hebaus, G.G., 1981, "Ultimate Dimension of Local Scour" Journal of Hard. Div., ASCE, Vol. 107, No. HY3, Proc. Paper 16144, March, PP.327-337.

3. Carstens, M.R. "Similarity Laws for Localized Scour", J. of Hyd. Div ASCE, 92 No. HY.3, Proc. Paper 4818, PP. 13-36, May 1966.

4. Farhoudi, J. and Smith, K.V.H., " Time Scale for Scour Downstream of Hydraulic Jump “, J. of Hyd. Div., ASCE, VoL. 10 8, HY10, Proc. Paper 17393, PP. 1147 - 1162, Oct. 1982.

5. Groot, M.B., Bliek, A.J., and Rossum, H.V., " Critical Scour : New Bed protection, Design method”, J. of Hydr. Engineering Vol. 114, No. 10, October, 1988.

6. Hong " Quasi- Two Dimensional Simulation of Scour and Deposition in Alluvial Channels" Journal of Hyd. Eng., Vol 123, No. 7, July, 1997.

7. Ali and Hadya "Local Scour Profiles Downstream a Standing Wave Weir", Civil Eng. Research magazine, Faculty of Eng. Al-Azhar University, Nasr City, Cairo, Egypt Volume(14)-No.6 June 1992.

8. Hoffmans, J.C.M. and krystian w.," Local Scour Downstream of Hydraulic Structures" J. of Hyd. Eng., Vol. 121, No. 4, ASCE, Apr. 1995.

9. Negm, A. M., " Effect of Sill Arrangement on Maximum Scour Depth Downstream of Abruptly Enlarged Stilling Basins “ Eighth International Water Technology Conference, TWTC8, Alexandria, Egypt, 2004. 


\section{تحديد النحر الموضعى حول خوازيق الكبارى باستخام الثبكات العصبية الاصطناعية}

ان التصميم الامن والاقتصادى للكبارى فوق المجارى المائية يتطلب تحديد دقيق لعمق النحر حول

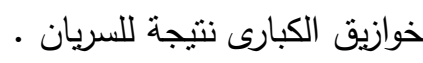
كما يعتبر النحر حول خوازيق الكبارى من اهم الاسباب التى تؤدى الى عدم اتزان اساسات الكبارى

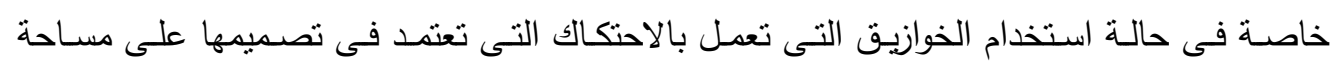

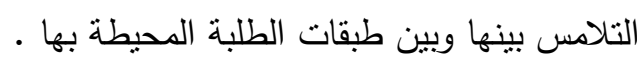
يعرف النحر على انه الهبوط الحادث فى منسوب قاع المجرى المائى حول الخوازيق نتيجة للسريان بهان

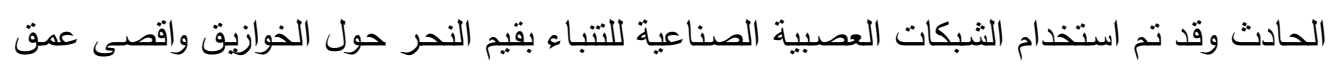

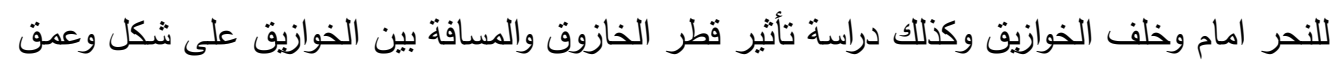
حفرة النحر وذلك عند قيم مختلفة لكميات التصرف المار بالمجرى المائى وامكن التوصل الى الثئ النتائج الاتية

1 - اقصى عمق للنحر يحدث دائما امام الدعامة الاولى وملاسق لها . 2 - بزيادة قطر الدعامة يزداد عمق النحر امام الدعامات

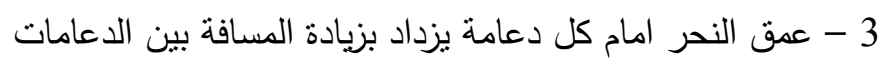

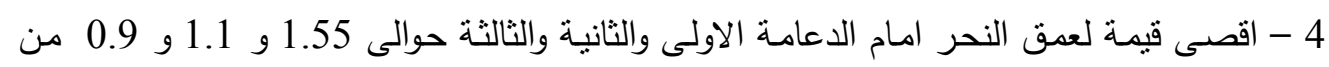
عمق النحر للاعامة المفردة بالترتيب 5 - اقصى قيمة لعمق النحر امام الدعامة الاولى يقترب من اقصى قيمة لعمق النحر حول الدعامة S/D = المفردة عند 1 